\title{
Analysis Related to the Application of E-billing Payment Method and Manufacture as Concerned Tax Deposit (SSP) Manual Towards the Understanding of Tax Mandatory
}

\author{
${ }^{1}$ Nur Widyawati, ${ }^{2}$ Larasati, ${ }^{3}$ Juli Prastyorini \\ STIA dan Manajemen Kepelabuhan Barunawati Surabaya \\ 1nur.widyawati@stiamak.ac.id, 3juli.prastyorini@stiamak.ac.id
}

\begin{abstract}
Tax is the biggest source of APBN income in Indonesia. Various payment applications use the e-billing method or manually. A guide for learn about the effect of applying the e-billing payment method and tax payment slip (SSP) to the understanding of taxpayers. This research is quantitative research. Data collection techniques by giving questionnaires to consumers, conduct observations, interviews, and study relevant literature. The sampling technique uses probability sampling so that a sample of 70 from PT. Kartini Patent. The results showed that there was no significant effect between the e-billing payment methods on the understanding of taxpayers, while the positive and significant effect was shown on the method of manual payment of tax payments (SSP) on mandatory understanding. Based on the results of correlation analysis, this study obtained a value of 0.119 or $11.9 \%$ which means it has a very low relationship between the independent and dependent variables.
\end{abstract}

Keywords: Tax, E-billing, Tax Payment, Understanding Taxpayers

\section{INTRODUCTION}

Taxes are mandatory government levies based on the law. Taxes are the largest source of state budget revenues in Indonesia. Various payment applications use the e-billing method or manually. Currently the tax collection system in Indonesia has experienced many significant changes, namely the Official Assessment System to become a Self Assessment System, which is that taxpayers are given the trust to calculate, deposit and report themselves according to calculations and data owned by taxpayers themselves. Knowledge of taxation can foster a willingness to pay taxes because in learning matters relating to taxation it will be easier for taxpayers to understand in the process of calculation, tax reporting, and how to pay taxes. It is expected that taxpayers can learn and understand the importance of tax reporting for the interests of the State.

In implementing the manual payment method for taxpayers, a Tax Payment (SSP) form is still needed in the form of information regarding tax payment. With this manual system, taxpayers can pay taxes through a form that is only filled in according to the intended deposit and then continue the payment process to the Bank / Post Office Perception. In the process of tax payments that are still manual, it is very necessary to anticipate errors in filling in types, codes, and even the amount of deposits made by the tellers of the Bank / Post Office Perception because in this way not only the taxpayers themselves are blamed but those who assist the transaction process the.

Facing increasingly rapid technological developments, the Directorate General of Tax (DJP) does not want to be left behind in utilizing technology to facilitate and streamline work related to administration and tax payments. Like online services in payment transactions that have been implemented in Indonesia, making the taxation system that was still manual now begins to implement an online-based taxation system. Therefore $D J P$ released a new program, e-billing, to facilitate the tax payment process through Electronic Deposit (SSE). 
E-billing is a method for paying taxes online and through ATMs by entering the billing code that will be accepted by the Taxpayer. To accommodate the transfer of tax payments from the manual to the online system through e-billing, several state-owned banks such as Bank Mandiri, Bank Negara Indonesia (BNI), Bank Rakyat Indonesia (BRI), and the Bank Tabungan Negara (BTN) and PT. Pos Indonesia previously mentioned can help the process of tax payment transactions. With the latest $e-$ billing method, it is expected to provide convenience for taxpayers because the entire set of methods can be accessed anywhere and anytime by taxpayers.

However, in reality on the ground not all taxpayers in Indonesia accept service system changes from the Directorate General of Taxes $(D J P)$ which were previously still manually now switched to the online system. In connection with this, an understanding of taxpayers is needed to be able to follow the development of advanced technology, especially for taxpayers who are elderly; they really need guidance in the process of both tax reporting and how to pay taxes.

The role of tax consultants in the digital era today is very much needed by taxpayers who want to use their services to help them solve all problems and difficulties experienced by clients / taxpayers. PT. Kartini Patent is a company engaged in the field of consultation and taxation that has a license or a valid permit from an authorized agency to actually become a registered tax consultant.

From the description above background, the authors are interested in conducting a study in the company PT. Kartini Patent as a company in the field of consulting and taxation services, the writer will take respondents from clients / taxpayers who use the services of tax consultants in the company. So the authors compile this research with the title "Analysis of the Implementation of $E$ billing Payment Methods and Tax Payment Deposits (SSP) Manual on Understanding Taxpayers."

\section{Formulation of the problem}

The formulations of the problem in this study are:

1. How does the implementation of e-billing payment methods affect taxpayer understanding?

2. How does the effect of applying the method of manual payment of Tax Payment (SSP) to the understanding of taxpayers?

3. What is the effect of applying the e-billing payment method and the Tax Collection Letter $(S S P)$ together manually to the understanding of taxpayers?

\section{Research purposes}

The purpose of this study was to determine the effect of applying the e-billing payment method and manual tax payment $(S S P)$ to the understanding of taxpayers.

\section{Benefits of Research}

From the results of the research to be carried out, it is expected to be beneficial to the parties concerned which can be explained as follows:

1. To find out the analysis of the implementation of the e-billing system and the Tax Payment Deposit (SSP) manual on understanding taxpayers.

2. As a description of the company to decide on a policy within the company.

3. As a reference material for other researchers who will conduct research on the same object or problem. 


\section{LITERATURE REVIEW}

\section{Understanding Tax}

According to PJA Adriani in Waluyo (2011: 2), "Taxes are dues to the state (which can be forced) that are owed by those who are obliged to pay them according to regulations, with no achievements, which can be directly appointed, and the purpose is to finance public expenditures related to the duty of the state which runs the government ".

Meanwhile according to Prof. Dr. Rochmat Soemitro, SH. quoted by Mardiasmo (2011: 3) states that, "Tax is a public contribution to the state treasury based on the law (which can be forced) by not getting reciprocal services (counterparts) which can be directly shown and used to pay public expenses"

\section{Tax function}

According to Waluyo (2011), there are two tax functions, which are as follows:

1. Function of Receiving (Budgeter)

The tax serves as a source of funds earmarked for financing government expenditures, For example: the inclusion of the APBN as domestic revenue.

2. Regulating Function (Regular)

The tax serves as a tool to regulate or implement policies in the social and economic fields, for example: higher taxes imposed on liquor, can be suppressed. Likewise, luxury goods

\section{Understanding E-billing}

E-billing is a tool for making online tax payments (e-billing) that offers convenience in paying taxes through online payments with the advantages of being easy, convenient, fast, and flexible. According to Fauzie Aji (2014), "Tax administration reform is the improvement or improvement of administrative performance both individually, in groups, and institutionally to make it more efficient, economical, and faster". e-billing is a manifestation of a modern administrative system to be more efficient, economical and fast which is intended to increase understanding of taxpayer reports. Avoid mistakes from recording transactions. Sometimes in manual payments there are some recording errors that may occur. e-billing can minimize errors in recording transactions that can occur on manual payments.

\section{Understanding Tax Deposit (SSP)}

Tax Payment Letter is a letter that is used by taxpayers to make payments or deposits of tax owed to the State treasury through the Post Office and or Bank of State-Owned Enterprises or Regional-Owned Enterprises Bank or other payment places designated by the Minister of Finance.

\section{Understanding Taxpayer Taxation}

Understanding taxation regulations is the process by which taxpayers know about taxation and apply that knowledge to pay taxes, Suryadi (2006) in Hardiningsih (2011) in his research stated that increasing tax knowledge both formal and non-formal will have a positive impact on taxpayer awareness in paying tax. Gardina and Hariyanto (2006) in Hardiningsih (2011) found that the low compliance of taxpayers in paying taxes is caused by taxpayer knowledge and perceptions about tax and tax officials who are still low. 


\section{Hypothesis}

\section{Theoretical Framework}

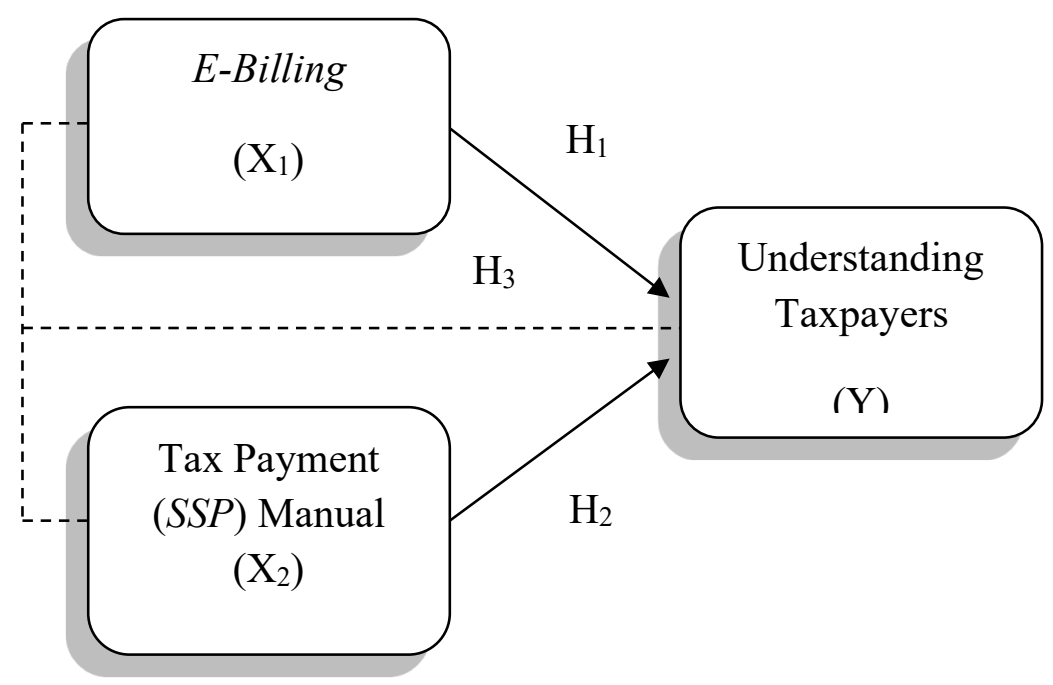

\section{E-billing and understanding of taxpayers}

According to Research Kania et al, (2017) shows that the online payment system has a positive and significant effect on taxpayers. e-billing has a positive and significant effect on the level of tax compliance. This is because there is a partial effect between e-billing implementation variables on the level of tax compliance. And the same research according to Husnurrosyidah \& Suhadi, (2017) and Sidharta, (2015) research shows that e-billing has a significant effect on taxpayer compliance. This is because e-billing is a manifestation of a modern administrative system to be more efficient, economical and fast which is intended to increase taxpayer compliance. Based on the literature, the following hypotheses are taken:

$\mathrm{H}_{1}=$ There is an effect of applying the e-billing payment method to the understanding of taxpayers.

\section{Tax Payment (SSP) Manual and Taxpayer Understanding}

In a previous study conducted by Dina (2011) manual tax payment by adding tax e-filling variables significantly affected tax revenue. In the same study Andiani (2012) states that tax knowledge and understanding make taxpayers a positive effect on taxpayer compliance. Based on the literature, the following hypotheses are taken:

$\mathrm{H}_{2}=$ There is an effect of the application of the method of manual payment of Tax Payment (SSP) on the understanding of taxpayers.

\section{E-billing, Tax Payment (SSP) Manual and Taxpayer Understanding}

The indicators used in the Understanding of Government Regulation Number 46 Year 2013 are indicators according to Fatmawati (2015), including Taxpayer Knowledge related to General Provisions of Government Regulation Number 46 Year 2013 which includes the enforcement of regulations and the contents of regulations (objects and subjects subject to regulations), and an indicator of the ability of taxpayers to be technically related to Government Regulation Number 46 of 2013 both in the procedure for its calculation and in its implementation. Based on the literature, the following hypotheses are taken: 
$\mathrm{H}_{3}=$ There is an effect of applying the e-billing payment method, manual Tax Payment (SSP) to the understanding of taxpayers.

\section{RESEARCH METHODOLOGY}

\section{Types of research}

The type of method used in this research is quantitative method. According to Sugiyono (2013: 13) "Quantitative research methods can be interpreted as a research method based on the philosophy of positivism, used to examine certain populations or samples, sampling techniques are generally carried out randomly, data collection using research instruments, data analysis is quantitative / statistics with the aim to test the hypothesis that has been set ". The location of this research was conducted in the company of PT. Kartini Patent in the tax section located at JI. Kartini No. 88 A Surabaya.

\section{Definition of Variable Operations}

Understanding according to Sugiyono (2011: 38), Variable is an attribute or nature or value of people, objects or activities that have certain variations determined by researchers to be studied and then drawn conclusions. In this study the authors used two interrelated variables, namely:

1. Independent Variable $(X)$

According to Sugiyono (2011: 39), the independent variable or the independent variable is referred to as the stimulus, predictor, antecedent variable is the variable that influences or which causes the change or emergence of the dependent variable or the dependent variable. In this study the independent variable used was the application of the e-billing payment method and a manual Tax Payment Deposit (SSP).

2. Dependent Variable $(X)$

According to Sugiyono (2011: 39), the dependent variable or the dependent variable is often referred to as the output variable, the criterion, the consequent is the variable that is affected or which is due to the independent variable. The dependent variable used in this research is taxpayer understanding.

Table 1. Variable Operations

\begin{tabular}{|c|c|c|c|}
\hline Variables & Indicator & Scale & Source \\
\hline $\begin{array}{l}\text { E-billing } \\
\left(\mathrm{X}_{1}\right)\end{array}$ & $\begin{array}{l}\text { Taxpayer understanding of the application set by the } \\
\text { Directorate General of Taxes about e-billing. } \\
\text { Understanding Taxpayers regarding the use of e- } \\
\text { billing systems } \\
\text { Taxpayer perception regarding e-billing convenience. } \\
\text { Taxpayers' perception of the usefulness of e-billing. } \\
\text { Taxpayer's satisfaction in using e-billing. }\end{array}$ & Likert & Ryan, 2017 \\
\hline $\begin{array}{l}\text { Manual Tax } \\
\text { Payment } \\
(S S P) \\
\left(\mathrm{X}_{2}\right)\end{array}$ & $\begin{array}{l}\text { Understanding Taxpayers use Tax Payment (SSP) } \\
\text { Taxpayers' perception of the ease of using a Manual } \\
\text { Tax Payment (SSP) } \\
\text { Satisfaction of taxpayers in using the manual system }\end{array}$ & Likert & $\begin{array}{l}\text { Dara Ayu, } \\
2016\end{array}$ \\
\hline
\end{tabular}




\begin{tabular}{|l|l|l|l|}
\hline Understanding & Know and try to understand tax laws & Likert & Widayati \\
Taxpayers & Knowledge and understanding of the rights and \\
obligations as a taxpayer & Knowledge and understanding of PTKP, PKP, and & & 2010 \\
& tax rates & & \\
& Knowledge and understanding of sanctions along \\
& with fines if taxpayers are late in paying taxes. \\
& Understanding of tax policies and regulations \\
& regarding tax payments. & & \\
& & &
\end{tabular}

\section{Population and Sample}

Definition according to Sugiyono (2011: 80), Population is the area of generalization consisting of objects or subjects that have certain qualities and characteristics determined by researchers to be studied and drawn conclusions. The populations in this study are all consumers who use the services of a tax consultant at PT. Kartini patent. While the sample according to Sugiyono (2011: 81), is part of the number and characteristics possessed by the population.

The method for determining the number of samples is to use the Slovin formula as follows:

$$
n=\frac{N}{1+N e^{2}}
$$

Information:

$\mathrm{n}=$ Number of samples

$\mathrm{N}=$ Number of population

$\mathrm{e}=$ Error tolerance limit

From the formula above we get the following results:

$$
n=\frac{N}{1+N e^{2}}=\frac{230}{1+230 \times 0,1^{2}}=69,69=70
$$

Based on, the numbers of samples above for this study as many as 70 consumers who use the services of a tax consultant at PT. Kartini Patent. In this study researchers used the probability sampling method.

The sampling used is simple random sampling is said to be simple (simple) because the sampling of members of the population is done randomly without considering the strata that exist in that population.

\section{ANALYSIS AND DISCUSSION}

\section{Overview of Research Objects}

PT. Kartini Patent is a company of the "Asiang group" because within the company itself has several sections in the field of Business Consultancy and Management Services such as Tax Consultant services, management of registration of Intellectual Property Rights (IPR), and Business Licensing. One of the companies in the field of business and management consulting services; where PT. Kartini Patent itself has a manager who has the ability to serve management in the field of business services and management. 


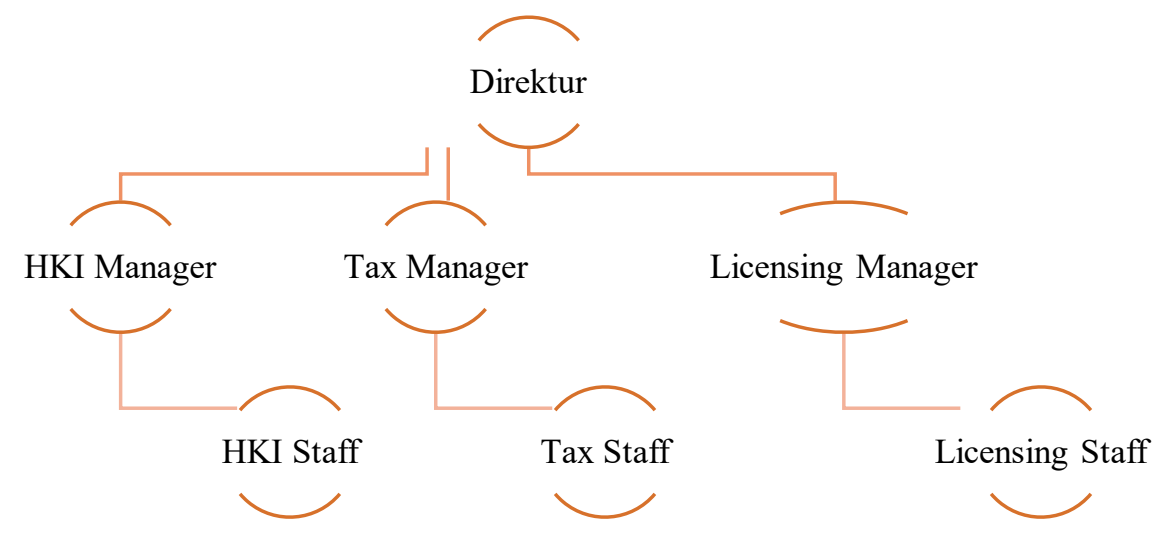

Figure 1. Organizational Structure of PT. Kartini Patent

Source: PT. Kartini Patent

\section{Characteristics of Respondents}

Respondents taken in this study are consumers or taxpayers who use services at PT. Kartini Patent. Through the list of statements submitted, obtained information about respondents gender and age. Classification is carried out on respondents in this study aims to find out clearly about the description of respondents as objects of 70 studies. General description of the respondents one by one can be described as follows:

Table 2. Respondents by Gender

\begin{tabular}{|c|c|c|}
\hline Gender & Total & Percentage \\
\hline Male & 42 & $60 \%$ \\
\hline Female & 28 & $40 \%$ \\
\hline Total & $\mathbf{7 0}$ & $\mathbf{1 0 0 \%}$ \\
\hline
\end{tabular}

Table 3. Respondents by Age

\begin{tabular}{|c|c|c|}
\hline Age & Total & Percentage \\
\hline $20-30$ & 12 & $17 \%$ \\
\hline $31-40$ & 27 & $39 \%$ \\
\hline $41-50$ & 17 & $24 \%$ \\
\hline$>50$ & 14 & $20 \%$ \\
\hline Total & $\mathbf{7 0}$ & $\mathbf{1 0 0 \%}$ \\
\hline
\end{tabular}

Validity Test Results

Table 4. Variable Validity Test $\left(\mathrm{X}_{1}\right)$

\begin{tabular}{|c|c|c|c|}
\hline $\begin{array}{c}\text { Statement } \\
\text { Items }\end{array}$ & $\mathbf{r}$ - count & $\begin{array}{c}\text { Pearson Product } \\
\text { Moment Table }\end{array}$ & Information \\
\hline $\mathrm{X}_{1.1}$ & 0.496 & 0.235 & Valid \\
\hline $\mathrm{X}_{1.2}$ & 0.413 & 0.235 & Valid \\
\hline $\mathrm{X}_{1.3}$ & 0.267 & 0.235 & Valid \\
\hline
\end{tabular}




\begin{tabular}{|c|c|c|c|}
\hline $\mathrm{X}_{1} 4$ & 0.452 & 0.235 & Valid \\
\hline $\mathrm{X}_{1} .5$ & 0.365 & 0.235 & Valid \\
\hline $\mathrm{X}_{1} .6$ & 0.245 & 0.235 & Valid \\
\hline $\mathrm{X}_{1.7}$ & 0.564 & 0.235 & Valid \\
\hline
\end{tabular}

Source: SPSS data 25

Based on the table above it can be seen that the number of statements in variable $X_{1}$ is 7 statements and declared valid.

Table 5. Variable Validity Test $\left(\mathrm{X}_{2}\right)$

\begin{tabular}{|c|c|c|c|}
\hline $\begin{array}{c}\text { Statement } \\
\text { Items }\end{array}$ & $\mathbf{r}$-count & $\begin{array}{c}\text { Pearson Product } \\
\text { Moment Table }\end{array}$ & Information \\
\hline $\mathrm{X}_{2.1}$ & 0.602 & 0.235 & Valid \\
\hline $\mathrm{X}_{2 .}$ & 0.715 & 0.235 & Valid \\
\hline $\mathrm{X}_{2.3}$ & 0.302 & 0.235 & Valid \\
\hline $\mathrm{X}_{2 .} .4$ & 0.247 & 0.235 & Valid \\
\hline $\mathrm{X}_{2.5}$ & 0.749 & 0.235 & Valid \\
\hline
\end{tabular}

Source: SPSS data 25

Based on the table above it can be seen that the number of statements in variable $X_{2}$ is 5 statements and is declared valid.

Table 6. Variable Validity Test (Y)

\begin{tabular}{|c|c|c|c|}
\hline $\begin{array}{c}\text { Statement } \\
\text { Items }\end{array}$ & r-count & $\begin{array}{c}\text { Pearson Product } \\
\text { Moment Table }\end{array}$ & Information \\
\hline Y.1 & 0.666 & 0.235 & Valid \\
\hline Y.2 & 0.771 & 0.235 & Valid \\
\hline Y.3 & 0.659 & 0.235 & Valid \\
\hline Y.4 & 0.703 & 0.235 & Valid \\
\hline Y.5 & 0.794 & 0.235 & Valid \\
\hline Y.6 & 0.803 & 0.235 & Valid \\
\hline Y.7 & 0.427 & 0.235 & Valid \\
\hline Y.8 & 0.254 & 0.235 & Valid \\
\hline Y.9 & 0.603 & 0.235 & Valid \\
\hline
\end{tabular}

Source: SPSS data 25

Based on the table above it can be seen that the statements on variable $Y$ are 9 statements and are declared valid.

\section{Reliability Test Results}

Table 7. Reliability Test

\begin{tabular}{|c|c|c|c|}
\hline Variable & $\begin{array}{c}\text { Cronbach } \\
\text { Alpha }\end{array}$ & Criteria & Information \\
\hline E-billing $\left(\mathrm{X}_{1}\right)$ & 0.677 & 0.6 & Reliabel \\
\hline Manual Tax Payment $(S S P)\left(\mathrm{X}_{2}\right)$ & 0.750 & 0.6 & Reliabel \\
\hline Understanding Taxpayers $(\mathrm{Y})$ & 0.799 & 0.6 & Reliabel \\
\hline
\end{tabular}

Source: SPSS data 25 
Based on the table above it is known that each variable has a Cronbach alpha value higher than 0.6 , then the variable can be said to be reliable. Thus the reliability requirements of the measuring instrument are met.

\section{Classic assumption test}

1. Normality Test

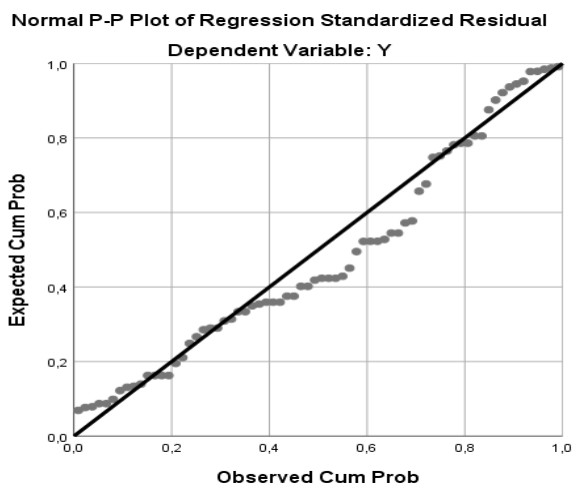

Figure 2. Normality Test, (Source: SPSS data 25)

Based on the results of the normality test above, it can be seen that the point distribution (data) on the diagonal axis does not spread far from the diagonal line or follow the direction of the diagonal line, it can be stated that the regression model meets the normality assumption.

2. Heteroscedasticity Test

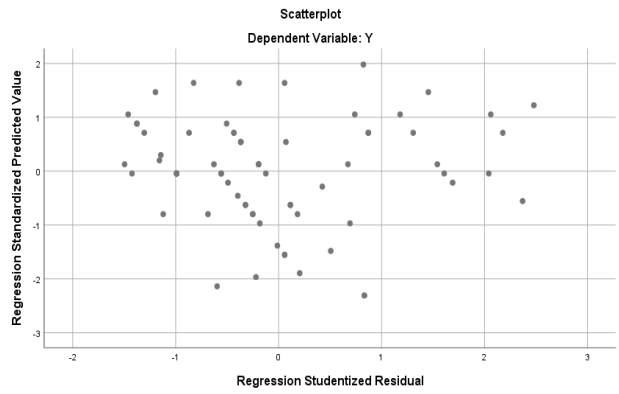

Figure 3. Heteroscedasticity Test, (Source: SPSS data 25)

Based on the results of the scatterplot heteroscedasticity test above shows that the points spread above and below the axis (0) and do not form a pattern, so it can be concluded that the data does not occur heteroscedasticity problems.

3. Multicollinearity Test

Table 8. Multicollinearity Test

\begin{tabular}{|c|c|c|c|}
\hline \multicolumn{2}{|c|}{ Model } & \multicolumn{2}{c|}{ Collinearity Statistics } \\
\cline { 3 - 4 } \multicolumn{2}{|c|}{} & Tolerance & VIF \\
\hline 1 & (Constant) & & \\
\cline { 2 - 4 } & X1 &, 993 & 1,007 \\
\cline { 2 - 4 } & X2 &, 993 & 1,007 \\
\hline
\end{tabular}

Dependent Variable: Y, (Source: SPSS data 25)

Based on the table above, it can be concluded that the variables $X_{1}$ and $X_{2}$ do not have multicollinearity. This is because the multicollinearity test results have met the VIF assumptions. 
Table 9. Linearity Test

\begin{tabular}{|l|c|c|c|}
\hline \multicolumn{1}{|c|}{ Linierity } & $\begin{array}{c}\text { Deviation } \\
\text { from } \\
\text { Linearity }\end{array}$ & Alpha & Conclusion \\
\hline E-billing $\left(\mathrm{X}_{1}\right)$ & 0,233 & 0.05 & Linier \\
\hline Manual Tax Payment $(\mathrm{SSP})\left(\mathrm{X}_{2}\right)$ & 0,961 & 0.05 & Linier \\
\hline
\end{tabular}

\section{Source: SPSS data 25}

Based on the linearity test results in table 4.6 above, it is known that the value of Deviation From Linearity $>0.05$, it can be concluded that e-billing $\left(X_{1}\right)$ and manual tax payment slip $\left(X_{2}\right)$ each have a linear relationship to the understanding of taxpayers $(Y)$.

\section{Multiple Linear Regression Analysis}

Regression analysis is used to determine the extent of the relationship between the independent variables and the dependent variable. Based on the regression analysis using SPSS, the following results are obtained:

Table 10. Multiple Linear Regressions

\begin{tabular}{|c|c|c|c|c|c|c|}
\hline \multirow{2}{*}{ Model } & \multicolumn{2}{|c|}{ Unstandardized Coefficients } & $\begin{array}{c}\text { Standardized } \\
\text { Coefficients }\end{array}$ & \multirow{2}{*}{$\mathrm{t}$} & \multirow{2}{*}{ Sig. } \\
\cline { 3 - 5 } \multicolumn{2}{|c|}{} & B & Std. Error & Beta & & \\
\hline \multirow{2}{*}{1} & (Constant) & 17,716 & 7,623 & & 2,324 &, 023 \\
\cline { 2 - 7 } & $\mathrm{X} 1$ &, 161 &, 219 &, 083 &, 732 &, 467 \\
\cline { 2 - 7 } & $\mathrm{X} 2$ &, 710 &, 222 &, 364 & 3,206 &, 002 \\
\hline
\end{tabular}

Source: SPSS data 25

Based on the results of the above calculations, we get the following linear regression equation:

$$
Y=17,716+0,161 X_{1}+0,710 X_{2}+\varepsilon
$$

Statistical test results obtained as follows:

1. Constant value $(\alpha)$ of $\mathbf{1 7 . 7 1 6}$ means that if the independent variable (e-billing and manual tax payment slip) is assumed to be zero (0), then the variable on understanding taxpayers has a value of 17.716 , because the constant shows a value of 17.716 .

2. The e-billing coefficient $\left(X_{1}\right)$ value of 0.161 indicates that the e-billing variable $(X 1)$ has a positive relationship with the understanding of taxpayers $(\mathrm{Y})$. This means that the better the e-billing payment method, the better the understanding of taxpayers. Value $\beta 1=0.161$, meaning that if the method of applying e-billing increases one-unit, then the understanding of taxpayers will increase by 0.161 with a value of $\mathrm{X} 1$ considered constants.

3. The coefficient value of manual tax collection $\left(\mathrm{X}_{2}\right)$ of 0.710 indicates that the variable of manual tax payment $\left(\mathrm{X}_{2}\right)$ has a positive relationship with the understanding of tax obligation $(\mathrm{Y})$. This means that the better the method of applying the manual tax payment method, the better the understanding of taxpayers. 


\section{Hypothesis Test Results}

1. Partial Test (t Test)

$T$ test is used to determine whether the independent variable partially influences the dependent variable. Based on the results of the t test carried out, the following results are obtained:

Table 11. Test Results $\mathrm{t}$

\begin{tabular}{|c|c|c|c|c|c|c|}
\hline \multirow{2}{*}{ Model } & \multicolumn{2}{|c|}{$\begin{array}{c}\text { Unstandardized } \\
\text { Coefficients }\end{array}$} & $\begin{array}{c}\text { Standardized } \\
\text { Coefficients }\end{array}$ & \multirow{2}{*}{$\mathrm{t}$} & \multirow{2}{*}{ Sig. } \\
\cline { 3 - 7 } & B & Std. Error & Beta & & \\
\hline \multirow{3}{*}{1} & (Constant) & 17,716 & 7,623 & & 2,324 &, 023 \\
\cline { 2 - 7 } & X1 &, 161 &, 219 &, 083 &, 732 &, 467 \\
\cline { 2 - 5 } & X2 &, 710 &, 222 &, 364 & 3,206 &, 002 \\
\hline
\end{tabular}

Source: SPSS data 25

The t-table value is known at the $5 \%$ significance rate using the following equation:

$$
\begin{aligned}
\mathrm{t}-\text { tabel } & =\mathrm{t}(\alpha / 2 ; \mathrm{n}-\mathrm{k}-1) \\
& =\mathrm{t}(0,05 / 2 ; 70-2-1) \\
& =\mathrm{t}(0,025 ; 67) \\
& =1,99601
\end{aligned}
$$

Information:

$\mathrm{n}=$ number of samples

$\mathrm{k}=$ number of independent variables

$1=$ constant

From the calculation above, the following results are obtained :

a. The e-billing variable has a t-count of $0.732<t$-table 1.99601 and a significance of $0.467>0.05$ meaning that e-billing does not partially have a significant influence on the understanding of taxpayers.

b. The variable manual tax payment has a t-count of 3.206>t-table 1.99601 and a significance of $0.002<0.05$ means that the manual tax payment partially has a significant influence on the understanding of taxpayers.

\section{Simultaneous Test (Test F)}

The $\mathrm{F}$ test is used to find out whether the independent variables together have a significant effect on the dependent variable. The alpha value used is 0.05 . The following $F$ test results have been carried out:

Table 12. Test Results F ANOVAa (Source: SPSS data 25)

\begin{tabular}{|l|l|c|c|c|c|c|}
\hline \multicolumn{2}{|c|}{ Model } & Sum of Squares & df & Mean Square & $F$ & Sig. \\
\hline 1 & Regression & 61,034 & 2 & 30,517 & 5,642 &, $005^{\mathrm{b}}$ \\
\cline { 2 - 7 } & Residual & 362,408 & 67 & 5,409 & & \\
\cline { 2 - 7 } & Total & 423,443 & 69 & & & \\
\hline
\end{tabular}


The known F-count is 5.642 with a significance of 0.005 . The F-table calculation is done in the following way:

$$
\begin{aligned}
\text { F-tabel } & =F(k ; n-k) \\
& =F(2 ; 70-2) \\
& =(2 ; 68) \\
& =3,13
\end{aligned}
$$

Information:

$\mathrm{n}=$ number of samples

$\mathrm{k}=$ number of independent variables

From the calculation above, the F-count result is $5.642>\mathrm{F}$-table 3.13 with a significance of 0.005 , which means that $\mathrm{H} 0$ is rejected and $\mathrm{H} 1$ is accepted. Based on these results it shows that $e$-billing and manual tax collections together have a significant effect on understanding taxpayers.

\section{Correlation Coefficient Test $(R)$ and Determination Coefficient $\left(\mathbf{R}^{2}\right)$}

To find out how big is the correlation or the relationship between the independent and dependent variables, it can see the value of the correlation coefficient or $(R)$. Whereas to measure how far the ability of the independent variable can provide the information needed to explain the dependent variable is to use the coefficient of determination $\left(R^{2}\right)$.

The results of the correlation coefficient $(R)$ and the coefficient of determination $\left(R^{2}\right)$ can be seen in the following table:

Table 13. Correlation Coefficient Test Results and Determination Coefficient Model Summary ${ }^{b}$ (Source: SPSS data 25, 2019)

\begin{tabular}{|c|c|c|c|c|}
\hline Model & $\mathrm{R}$ & $\mathrm{R}$ Square & Adjusted R Square & Std. Error of the Estimate \\
\hline 1 &, $380^{\mathrm{a}}$ &, 144 &, 119 & 2,326 \\
\hline
\end{tabular}

a. Predictors: (Constant), X2, X1

b. Dependent Variable: $Y$

Based on the table above, the magnitude of the correlation value $(R)$ obtained is 0.380 . This shows that there is a low relationship between the independent variable and the dependent variable. While the magnitude of the Adjusted $R$ Square $\left(R^{2}\right)$ multiple determination coefficients obtained is 0.119 , which means that the e-billing variable and manual tax payment letter have an effect of $11.9 \%$ on the understanding of taxpayers, while the rest is influenced by other variables that are not scrutinized.

\section{Discussion}

1. The effect of applying the e-billing payment method to the understanding of taxpayers.

The first hypothesis examines the effect of applying the e-billing payment method to the understanding of taxpayers. The results of the $t$ test show that there is no significant effect between $e-$ billing payment methods on the understanding of taxpayers with a regression coefficient of 0.083 and the results of the t-test analysis of 0.732 <of the t-table value of 1.99601 and a significance level of 0.467 , thus in hypothesis $\left(\mathrm{H}^{1}\right)$ which states that there is an effect of applying the e-billing payment method to the understanding of the taxpayer being rejected. 
Sarunan (2015) in his theory states that research shows that the results of the modernization of the tax administration system have insignificant influence on the understanding of taxpayer understanding. This encourages tax revenue because in its modern application does not affect taxpayers in paying tax compliance.

2. The effect of applying the method of manual payment of Tax Payment (SSP) on the understanding of taxpayers.

The second hypothesis examines the effect of applying the method of manual payment of Tax Payment $(S S P)$ on the understanding of taxpayers. The results of the test show that there is a positive and significant influence between the method of manual payment of Tax Payments (SSP) on mandatory understanding with a regression coefficient of 0.364 and the results of the t-test analysis of 3.206> of the t-table value of 1.99601 and the level of significance equal to 0.002 , so the results of this study support the hypothesis that has been established that there is an influence of the application of the method of payment of the Tax Payment (SSP) manual on understanding taxpayers $\left(\mathrm{H}^{2}\right)$ received.

In the results of previous studies by Sendy Estika R. (2017) which states when significant results on manual tax payments indicate that with the expansion of subjects and taxes are expected to be able to make taxpayers who previously did not pay taxes can perform their tax obligations as stipulated in the tax law existing by increasing understanding of taxpayers.

3. The effect of applying the e-billing payment method and the Manual Tax Payment (SSP) together on the understanding of taxpayers

The third hypothesis examines the effect of applying the e-billing payment method and the manual Tax Payment Deposit (SSP) together has a significant effect on the understanding of taxpayers. This is evident from the results of the analysis of the F-test of 5.642> of the F-table value of 3.13 with a significance level of $0.005<$ significant probability $\alpha=0.05$. Thus the results of this study support the hypothesis that has been established that there is an effect of the application of the e-billing payment method and the Tax Payment Deposit (SSP) together on the understanding of taxpayers $\left(\mathrm{H}_{3}\right)$ received.

This research is in line with the results of research conducted by Natrah Saad (2014) on Tax Knowledge, Tax Complexity, and Tax Compliance: Taxpayers' View. One of the results of this study suggests that knowledge about taxation can be an influence on taxpayer compliance.

\section{CONCLUSION}

1. The application of the e-billing payment method $\left(X_{1}\right)$ does not have a significant effect on the understanding of taxpayers referred to as consumers of PT. Kartini Patent. where consumers from PT. Kartini Patent who is a more dominant taxpayer already has a lot of understanding of all tax regulations, this is because the results of the services of tax consultants at PT. Kartini Patent has been going well by following the procedures.

2. The application of the manual tax payment method $\left(X_{2}\right)$ has a significant effect on the understanding of taxpayers who are consumers of PT. Kartini Patent. This can happen due to the age factor of consumers who limit the ability to understand tax regulations, especially in tax reform that already uses electronic or online systems, thus affecting the understanding of taxpayers in paying taxes.

3. Simultaneously the independent variable, e-billing $\left(\mathrm{X}_{1}\right)$ and manual Tax Payment $\left(\mathrm{X}_{2}\right)$ together have a significant effect on the understanding of taxpayers who are consumers at PT. Kartini Patent. e-billing variables and manual tax payments provide an effect of $11.9 \%$ on the 
understanding of taxpayers for consumers in PT. Kartini Patent, while the rest are influenced by other variables.

\section{Suggestion}

1. As a consulting service company, PT. Kartini Patent maintains the quality of company services in order to maintain the trust of consumers who already feel helped from all problems, both taxation problems and other matters in the management.

2. PT. Kartini Patent lagar approaches consumers who are elderly to provide motivation and direction to make it easier to help understand all tax regulations and policies that have been set by the government so that consumers or taxpayers do not feel disadvantaged due to lack of understanding and knowledge of taxation.

3. From the results of the study, the lack of other factors not yet examined is expected for further research to add variables related to the tax revenue system, for example: e-Invoice, e-SPT, efilling, etc.

\section{REFERENCES}

Direktorat Jenderal pajak, Undang-undang 16 Tahun 2009 tentang Perubahan Ketiga atas Undang-undang Nomor 6 tahun 1983 tentang Ketentuan Umum dan tata Cara Perpajakan.

Hardiningsih, Pancawati dan Nila Yulianawati2011. Faktor-Faktor Yang Mempengaruhi Kemauan Membayar Pajak. DinamikaKeuangan dan Perbankan . Vol. 3, No. 1.Hal. 126 - 142.

Sugiyono. 2011. Metode Penelitian Kuantitatif, Kualitatif dan R\&D. Bandung: Afabeta

Mardiasmo. 2011. Perpajakan Edisi Revisi 2011. Yogyakarta: Penerbit Andi

Waluyo, 2011. Perpajakan Indonesia, Jakarta : Salemba Empat

Widayati dan Nurlis. 2010. "Faktor-faktor yang Mempengaruhi Kemauan untuk Pajak Wajib Pajak Orang Pribadi yang Melakukan Pekerjaan Bebas (Studi Kasus pada KPP Pratama Gambir Tiga)". Simposium Nasional Akuntansi XIII, Purwokerto.

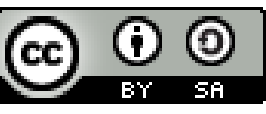

(C) 2020 by the authors. Submitted for possible open access publication under the terms and conditions of the Creative Commons Attribution (CC BY SA) license (https://creativecommons.org/licenses/by-sa/3.0/). 